\title{
Rastros do espírito \\ Fragmentos para a leitura de algumas fotografias dos Ramkokamekrá por Curt Nimuendaju
}

\author{
Francisco Simóes Paes \\ Mestrando em Antropologia Social - USP
}

\begin{abstract}
RESUMO: A partir de algumas fotografias de Curt Nimuendaju, o artigo apresenta um compêndio bibliográfico sobre os rituais de máscaras Timbira, uma daquelas "sociedades da palha", como bem disse Berta Ribeiro, e procura destacar, para além da visão, a importância que podem ter os outros quatro sentidos (tato, paladar, olfato e audição) no processo de significação do ritual indígena.
\end{abstract}

PALVRAS-CHAVE: Nimuendaju, índios timbira, ritual de máscaras, cinco sentidos.

\section{Aquém do olhar}

Nimuendaju tinha olhos especiais. Predestinados até, como o próprio nome que recebera cerimonialmente dos índios Apapocúva-Guarani indicava, já em 1906. Um ano depois de ser contratado pela Comissão Geográfica e Geológica de São Paulo, na qualidade de ajudante de cozinheiro, Curt Unkel (ou Unckle) é adotado pelos Apapocúva e recebe, na cerimônia do Nimongaraí realizada às margens do rio Batalha, o nome que passaria a assinar a partir de então. Diz-se, do nome, ser "o que cria 
Francisco Simôes Paes. Rastros do espírito

ou faz o seu próprio lar", "o que arranja um lugar para si”, "aquele que fez residência entre nós" ou, ainda, "aquele que soube abrir o seu próprio caminho neste mundo e conquistou o seu lugar" (Grupioni, 1998, p. 174).

Sua sina foi assim resumida a Herbert Baldus, em carta de 1939: "Quer que lhe mande uma história de minha vida? É simples - nasci em Jena, no ano de 1883, não tive instrução universitária de espécie alguma, vim ao Brasil em 1903, tinha como residência permanente até 1913 São Paulo, e depois Belém do Pará, e em todo o resto foi, até hoje, uma série ininterrupta de exploraçóes, das quais enunciei na lista anexa aquelas que me lembro. Fotografia minha não tenho" .

"Nimuendaju" marcou o nome da maior autoridade no campo da etnologia indígena da primeira metade do século XX, a ponto de ser considerado uma figura lendária na disciplina, seu "pai fundador", conforme Cardoso de Oliveira $(1988)^{2}$. Sua atuação foi marcada pela versatilidade, tendo ele trabalhado para o Serviço de Proteção ao Índio em dois momentos distintos (1910-1915 e 1921-1923) e para diversas instituiçôes internacionais e nacionais. Destacam-se, no cenário internacional, o Museu de Etnologia de Berlim e o Museu de Gotemburgo, na Suécia, o Carnegie Institution, de Washington, e a Universidade da Califórnia, da qual fazia parte Robert Lowie. E, no Brasil, o Museu Paraense Emílio Goeldi, o Museu Nacional do Rio de Janeiro e o Museu Paulista, dos quais se aproximou definitivamente com a eclosão da Segunda Guerra Mundial e a dificuldade em angariar recursos para suas expedições junto às instituições internacionais ${ }^{3}$.

Segundo Grupioni (1998), a vida e a obra de Nimuendaju relacionam-se diretamente com a institucionalização da etnologia e do indigenismo nacional ${ }^{4}$. Para Viveiros de Castro (1987), Nimuendaju foi não somente o fundador da etnologia guarani contemporânea - com a publicação de As lendas da criação e destruição do mundo como fundamentos da religião dos Apapocúva-Guarani ([1914]1987) - como fundou tam- 
bém os estudos jê, deslocando a centralidade das pesquisas culturalistas tupi-guarani para os estudos funcionalistas e estruturalistas daqueles então marginais, os Jê do Brasil Central.

Suas três grandes monografias sobre os Jê - The Apinayé (1939), The Serent (1942) e The Eastern Timbira (1946) -, publicadas nos Estados Unidos com tradução de Robert Lowie, suscitaram, a partir da década de 60 do século passado, uma explosão de estudos que culminaram com a constituição do Harvard Central Brazil Research Project. Coordenados por David Maybury-Lewis (de Harvard) e por Roberto Cardoso de Oliveira (à época no Museu Nacional), os estudos produzidos no âmbito do Projeto Jê, assim como os trabalhos de Nimuendaju, tiveram, segundo Gordon (1996), um caráter contestatório em relação aos paradigmas antropológicos produzidos até então, presos a conceitos cunhados a partir de realidades socioculturais estranhas às sociedades das terras baixas sulamericanas e incapazes de contemplar as particularidades destas sociedades. Caracterizavam-nas mais por sua negatividade - uma cultura de savana tecnologicamente rudimentar, na qual enfatizavam a não produção de cerâmica e de outros artefatos ou a ausência de hierarquias sociais rígidas, por exemplo - do que por suas complexas instituiçôes e organizações sociais - metade exógamas matrilineares (no caso Bororo), metade não exógamas baseadas em princípios de nominação e em um sistema de classes de idade (no caso Timbira), clâs patrilineares (nos casos Xerente e Xavante), sistema de descendência dupla (no caso Apinayé) etc. ${ }^{5}$.

\section{Além de olhar}

A pretexto da publicação do volume comemorativo da Revista de Antropologia (volume 46/2), que completou 50 anos em 2003, encontramos nos arquivos de Egon Schaden, seu fundador, um velho envelope, 
Francisco Simôes Paes. Rastros do espírito

remetido pela Universidade de Bönn, contendo 11 fotografias de Curt Nimuendaju distribuídas em quatro cartelas de cartolina e legendadas pelo próprio autor. Seis delas estão reproduzidas em The Eastern Timbira (1946, p. 336-41 do apêndice, pranchas 37, 38 e 39). Além das cartelas, não encontramos no arquivo nenhuma outra informação sobre as fotos, como também não sabemos a que se referem os números das legendas.

Estimulado pela riqueza do material iconográfico, pela notoriedade de seu autor e pelo ensejo de tornar acessível o material, José Guilherme Magnani, atual editor responsável pela Revista, solicitou-me que escrevesse algumas notas introdutórias para acompanhar o ensaio fotográfico publicado adiante (p. 297-307).

As imagens grafam um ritual Kokrit-ho dos índios Ramkokamekrá (Timbira) realizado em $1935^{6}$. Sua nitidez e sensibilidade, além das legendas que as acompanham, talvez fossem suficientes para proporcionar o gozo de quem as olha. Sem dúvida o são para demonstrar a acuidade e a meticulosidade que caracterizavam Nimuendaju ao descrever as realidades que presenciava.

O que pretendemos com estas "notas", portanto, não é tanto "explicar" as imagens em preto-e-branco, mas oferecer a elas uma "coloração" extra, de modo a evidenciar aspectos e conexões que acreditamos relevantes a sua leitura. Destarte, a partir do contexto ritual enunciado por este conjunto de fotogramas, limitados ao registro visual (bicolor, bidimensional e unisensorial), nossa intenção é oferecer fragmentos que indiquem a exploração do campo perceptivo do qual eles fazem parte, mas que não são "dados a ver". Quiçá possamos então "entre-ver" um pouco mais do que "sentiu" Nimuendaju quando, por trás de sua câmera fotográfica, presenciava o ritual, acreditando, com isso, que sua sensibilidade se estendia para muito além de seu olhar. Sua busca constante pela alteridade transpirando por todos os seus "sentidos". 
Revista de Antropologia, São Paulo, USP, 2004, v. 47 no 1.

\section{Baile de máscaras: os espíritos}

Uma vez tomada a decisão de realizar o ritual e de anunciar o evento ao restante da aldeia, a sociedade dos Kokrit dirige-se a um curso d'água algo distante e lá constrói um rancho, no qual destina-se a confeccionar as máscaras (fotografia 1$)^{7}$. É o próprio usuário da máscara que a confecciona, coletando a matéria-prima, trançando os folíolos de prefoliação do buriti e decorando-a. Com as folhas novas da palmeira amarradas a uma trança prévia, que por sua vez é presa a um suporte de varas cravado no chão, o artesão inicia o trançado diagonal (tipo espinha de peixe) da peça (fotografia 2$)^{8}$. Na borda superior é fixada uma estrutura horizontal de madeira que servirá de apoio para o mascarado dançarino. Berta Ribeiro, ao padronizar a taxonomia dos trançados indígenas brasileiros, elege a máscara Kokrit ramkokamekrá como modelo para a descrição das máscaras-esteira:

Indumentária ritual formada por duas esteiras suspensas de um suporte horizontal posto sobre a cabeça do usuário. Da borda inferior, pende uma pesada franja de palha de buriti, que cobre totalmente o corpo do mascarado". Dois "chifres" de pau roxo, de aproximadamente dois metros de comprimento, projetam-se da parte superior da máscara (fotografia 3). (Ribeiro, 1988, p. 307-8)

Nimuendaju (1946) ressalta ainda que na parte frontal da máscara existe uma fenda de cerca de um palmo, por onde o mascarado enxerga e por meio da qual ele se expressa. A fenda pode ser movida mediante dois cordões trançados, presos às suas beiradas, que o portador manipula com as mãos.

Pronto o trançado das máscaras, antes de iniciarem sua decoração, os membros da sociedade kokrit adornam-se com tinta preta e com ligas 
Francisco Simôes Paes. Rastros do espírito

de palha de buriti, dando assim a conhecer aos outros habitantes da aldeia que o início da festa ocorrerá no dia seguinte.

$\mathrm{Na}$ manhã do novo dia, obtendo a quantidade necessária de resina de almécega, elemento necessário à fixação das tintas, os artesãos iniciam a decoração das Kokrit-ho, pintando-as com vermelho e preto. Nimuendaju (1946, p. 203-4) identifica 11 tipos de motivos decorativos aplicados a elas, pintados de acordo com os personagens que representam. Como entre as fotografias de que dispomos figuram apenas três desses personagens, limitar-nos-emos a eles: Haká ("Haká-to-hók”, nas legendas de Nimuendaju), Mekratamtúa Tohók ("Me-kra-tamtuá-to/-hók”) e Tokaivéu ("To-kaivéu-ti”) ${ }^{10}$. A primeira, cuja tradução literal é "jibóia”, "apresenta listras formando um ângulo reto com o ápice no meio da borda superior, com losangos vermelhos sobre fundo preto. A cada faixa, por fora, corre uma linha preta. No verso apresenta 5 triângulos invertidos com fundo vazado", conforme podemos ler em Reis Lima (2003, p. 65); a segunda, Mekratamtúa Tohók, literalmente "que está vulnerável, frágil”, caracteriza-se por "duas linhas pretas duplas, formando um ângulo reto com o ápice no meio da borda superior da máscara" (idem); e a terceira, Tokaivéu, sem tradução, apresenta "olhos" com três círculos concêntricos e um ponto central, cujos espaços são tingidos de vermelho, "ouvidos", nas laterais, e "bigodes", franjas finas de envira de cada lado da fenda central. No verso apresenta quatro carreiras de pontos pretos (2003a, p. 78; 2003b, p. 65) ${ }^{11}$.

Após o término da confecção das máscaras, os mascarados seguem para a aldeia. No momento exato em que nela entram, ou mesmo antes, são rodeados violentamente pelas mulheres que pretendem tornarse "mães da máscara", amarrando em seus chifres pequenos enfeites de miçangas (fotografia 4).

Os Kokrit-ho, então, circulam pela aldeia (fotografia 5). Sua movimentação, entretanto, limita-se aos caminhos radiais (algo do gênero: 
centro-casa 1, casa 1-centro, centro-casa 2 etc.), nunca se estendendo às ruas circulares, familiares ${ }^{12}$.

Depois de algum tempo, o portador de uma máscara Tokaivéu, com um maracá (dance rattle) amarrado na ponta de um dos chifres, dirigese até a casa de um cantador e o chama para fora, batendo os pés e movendo as beiradas da fenda. Entregando ao cantador o instrumento, Tokaivéu carrega-o até o local do terreiro onde os outros Kokrit-ho formam um círculo ao redor das "moças associadas" e suas antecessoras, as Mekratamtúa Tohók.

Os Kokrit roncam surdamente, dando às vezes uma espécie de trinado a meia voz, balançando o corpo num pé e noutro. Em seguida as moças começam a cantar com voz clara, ao ritmo lento do maracá - fotografias 6 e 11. (Reis Lima, 2003b, p. 98) (13 $^{13}$

A sequiência é repetida diversas vezes. Em determinados momentos do ritual, os Kokrit se dirigem às casas de suas "mães" para buscar comida, levando-a em seguida para os conselheiros e chefes da aldeia que esperam no pátio.

Os Kokrit em geral têm um comportamento peculiar, geralmente são mudos ou fazem [emitem] um trinado a meia voz. (...) Para se comunicarem entre si ou com os outros índios, fazem movimentos com as beiradas da fenda vertical, da esteira dianteira da máscara. Estendem e encolhem as beiradas da fenda. Expressam contentamento, dançando e volteando as franjas. Se estiverem envergonhados por uma recusa [de alimento], abaixam a cabeça da máscara, e enfurecidos ameaçam o ofensor com o chifre. (idem) - fotografias 7 a 10. Esta cena acontece diariamente até resolverem terminar o rito. Geralmente depois de um mês. (idem, p. 104) ${ }^{14}$ 
Ainda segundo essa autora, os Kokrit promovem, durante todo o período de sua festa, corridas de tora, as quais eles mesmos fazem e adornam.

Antes da cerimônia final, os homens realizam uma caçada coletiva, enquanto as mulheres preparam a farinha de mandioca para os grandes bolos de carne cozidos em fornos de pedras e terra que serão distribuídos ao longo da cerimônia.

Dança-se durante toda a última noite. Ao final do ritual, no amanhecer do dia, os mascarados reúnem-se ao redor do forno de pedras e lá suas "mães" lhes tiram as máscaras e os lavam com água. As máscaras são jogadas no mato (Nimuendaju, 1946, p. 212) ${ }^{15}$.

\section{Fragmentos...}

Do nome KoKrit-ho (água e palHa): Para Nimuendaju (1946, p. 202), "Kokrit" denomina os monstros aquáticos que habitam o rio Tocantins $(k o=$ água $+k r i t=$ brabo $)$, referindo-se também à sociedade dos mascarados, encarregada de representá-los no ritual que antecede o período das chuvas. $\mathrm{O}$ autor acrescenta ainda que ao se referir à máscara, adiciona-se ho (= palha ou folha), ficando então Kokrit-ho. Para Melatti (1978, p. 267), o fragmento "krit", diferentemente da denominação de Nimuendaju, sugere "estar em presença" ou "companheirismo". Nesse caso, como acreditam Melatti, Castro (1994) e também Reis Lima (2003), o termo "Kokrit-ho" passa a indicar "seres associados à água" ou "os companheiros da água". As Kokrit-ho são as únicas máscaras feitas pelos Timbira.

DAS ORIGENS: Contaram os Ramkokamekrá a Nimuendaju (1946, p. 202) que, certa vez, a classe de idade mais nova caçava à beira do Tocantins acompanhada de um velho. Depois de os jovens matarem e 
Revista de Antropologia, São Paulo, USP, 2004, v. 47 № 1.

moquearem uma anta, o comandante da expedição resolveu retornar à aldeia. O grupo já estava distante do rio quando o velho percebeu que esquecera seu arco no acampamento. Como todos se negaram a acompanhá-lo, o velho, aborrecido, voltou sozinho. Ao alcançar a beira do Tocantins, viu-se cercado pelos Kokrit. Um dos monstros, que antes avistara os caçadores, voltou para chamar seus companheiros, mas estes, chegando ao local indicado, encontraram somente o velho. Alguns se precipitaram contra ele, ameaçando perfurá-lo com seus chifres. Fizeram-no suplicar por sua vida. Mas eis que chegou Kenpéy, chefe dos Kokrit (e também personagem-chefe do ritual), impedindo os outros de molestar o velho. Conduzindo-o para a aldeia dos Kokrit, Kenpéy tratou dele com esmero, incitando-o a observar com atenção as cerimônias que realizavam os monstros, pois deveria ensiná-las a seus companheiros. Quando o velho finalmente voltou para sua aldeia, ordenou aos Ramkokamekrá que fizessem máscaras de buriti exatamente como os verdadeiros Kokrit, demonstrando, em seguida, o ritual.

De maneira simétrico-invertida, referindo-se também à origem do mesmo ritual, os Krahó contaram a Melatti a seguinte narrativa, resumida pelo autor:

um rapaz, que andava caçando, viu muitos Kokrit dentro d'água. Foi correndo e avisou aos outros, que também quiseram vê-los. Quando chegaram à beira d'água, estavam aparecendo muitos. E os Kokrit fizeram festa dentro d'água. Os rapazes vieram e escutaram a cantiga deles. Depois os Kokrit foram embora, esquecendo um menino deles. Os rapazes levaram o menino-Kokrit para a aldeia. De noite os Kokrit foram até a aldeia. O fedor deles era muito forte e os índios que o sentiam iam morrendo. Os demais então fugiram para fora da aldeia. Daí passaram a realizar a festa que os rapazes tinham visto os Kokrit fazer. (1978, p. 269) 
Note-se, a partir desses dois fragmentos, as homologias, sobre as quais poderíamos discorrer longamente, entre esses e outros mitos sul-americanos. Basta-nos, a título de exemplo, citar os inúmeros mitos sobre a origem do fogo, dos nomes e dos rituais entre os Jê. Em todos eles, o protagonista (humano ou sobrenatural), por alguma razão inesperada, encontra-se isolado e abandonado, longe de seu lugar de origem, estado este que permite a ele entrar em contato com seres de outros domínios: jaguares, peixes, monstros Kokrit ou humanos. Estabelecida a relação (o protagonista sempre convive por algum tempo com esses outros seres), o herói ganha ou aprende algo que posteriormente será incorporado ao patrimônio cultural de seu povo, geralmente elementos distintivos de sua "humanidade" (plena predação, perspectivismo pleno) ${ }^{16}$.

Do BURITI: A bibliografia sobre os Ramkokamekrá e os Krahó ressalta a grande quantidade de objetos feitos de palmeiras para fins utilitários e rituais, acentuando a importância simbólica desta vegetação. Nimuendaju (1946) registra o buriti como a mais importante entre as diversas espécies vegetais empregadas pelos Timbira e chega a admitir que, se a palavra "timbira" for de origem tupi, pode conotar "os amarrados" - em que tin = amarrar, pira $=$ passivo - , referindo-se aos inúmeros adornos de palha (e também de algodão) que usam sobre o corpo. Os Timbira se autodenominam Mehím (gente) ${ }^{17}$.

Segundo Esther Castro,

o buriti compõe o universo ritual como alimento e matéria-prima para a confecção dos artefatos [diademas, cintos, pulseiras e colares] e toras. São raros os ritos que não têm início e término com seus participantes masculinos divididos em duas metades e realizando uma corrida ao redor da rua circular da aldeia, carregando, cada uma das metades, sua tora sobre os ombros. Esta tora é o caule do buriti. ${ }^{18}$ (1994, p. 16) 
Revista de Antropologia, São Paulo, USP, 2004, v. 47 № 1.

$\mathrm{Na}$ esfera cotidiana, Ladeira (1983) mostra como a presença das folhas de palmeira-de-buriti é constante nas casas timbira, desde o teto e a parede da casa aos utensílios domésticos - tipitis, abanos, cestos ou esteiras.

A esteira, por sua vez, acompanha toda a vida de um indivíduo, como se fosse uma extensão de seu próprio corpo. Logo ao nascer, diz-se que um bebê "cai na esteira" confeccionada por seu pai (Reis Lima, 2003b). Já pequena a criança começa a aprender sua confecção. As meninas possuem bonecas de buriti que, como elas, têm esteiras. Não se senta ou se deita em contato direto com o solo, somente sobre uma esteira. Sobre a esteira, os rapazes púberes têm suas orelhas perfuradas - os grandes botoques auriculares, usados pelos Krahó (como se vê à esquerda da foto 6, no homem que se acomoda sobre uma árvore), estão certamente relacionados com a importância de ouvir ${ }^{19}$. A esteira também acolhe o doente durante a cura do xamã. Ao morrer, enterra-se o falecido enrolado numa esteira e cobre-se sua cova com outra (Nimuendaju, 1946). Um indivíduo enlutado não pode trançar.

DA ÁGUA: Os buritizais vicejam no encontro dos elementos água e terra, como atestam Nimuendaju (1946) e Castro (1994). Também o mito isso corrobora: Sol e Lua encontravam-se em um buritizal no mundo intermediário. As palmeiras eram baixas, permitindo a Sol e Lua que apanhassem seus frutos com as mãos. Os frutos de Sol eram maduros e vermelhos, mas os de Lua, devido a um encantamento feito por Sol, eram verdes e escuros. Lua zangou-se e atirou com força um dos frutos no caule do buriti, que, imediatamente, começa a crescer até atingir a altura atual. Sol afirma então que não se poderá mais apanhar frutos de buriti apenas com as mãos e Lua justifica que assim poderão saber, de longe, onde há água (Nimuendaju, 1946). 
Melatti (1978) apresenta os Kokrit-ho em dois rituais krahó: o Kokrit e o Tépyarkwa, e classifica os dois como "ritos ligados à iniciação". Ambos são realizados na estação seca, o primeiro marca a passagem desta para o início do período chuvoso ${ }^{20}$. No Tépyarkwa, resumidamente, dois jovens são colocados em reclusão; ambos devem ficar, durante o rito, em quartos construídos dentro da casa materna de cada um. Esses jovens são denominados Koyampro. Ao final do ritual, os Koyampro são emplumados e levados à praça. Nesse momento, suas mães oferecem bolos de mandioca à aldeia. Em ambos os rituais, as máscaras caracterizam-se por "pedir comida".

A tradução literal de Koyampro nos é dada por Melatti (1978): "espuma de água". Aos reclusos é dito para ficar (simbolicamente) "dentro d'água". Melatti ressalta ainda que, no mito de origem associado ao ritual Tépyarkwa, a água faz os reclusos crescerem, e isto é colocado em evidência durante a cerimônia ${ }^{21}$. De fato, entre os Jê, a água é um elemento identificado com características propiciatórias para o desenvolvimento físico e psíquico, conforme Carneiro da Cunha: "a água marca o amadurecimento rápido e a inserção na sociedade, o banho de rio assinala, entre várias tribos jê, o fim do luto e da reclusão dos matadores, que assim retornam à sua vida social”22 (1987, p. 34).

Da Corporalidade: Além de a palmeira-de-buriti ser a matéria-prima das toras para as corridas e para os adornos corporais e utensílios de todo tipo, os Timbira utilizam também os frutos de uma outra palmácea, o babaçu, mas não tanto para fins comestíveis, como se poderia imaginar. Segundo Melatti, esse fruto "não é quase consumido pelos Krahó (...); guardam suas amêndoas, que obtêm mais longe, presas por um fio de algodão e as usam menos para comê-las do que para produzir o sumo com que fixam a tinta de urucum ao corpo. Fervem também as amêndoas em água, retirando o óleo que flutua sobre elas, que usam nos ca- 
belos" (1978, p. 41). Conforme Castro, "os cabelos compóem o que denominam “jeito certo de ser krahó”" (1994, p. 36). O coco-de-babaçu, seccionado ao meio, pode ainda ser utilizado como carimbo para pintura corporal, conforme Nimuendaju (1946) e Baldus (1961).

O corpo pode ser adornado com as cores vermelha e preta, sendo distintos os seus simbolismos. Nas palavras de Carneiro da Cunha,

o urucum, com efeito, não é tido como "pintura", mas como "tintura", e os Krahó usam verbos diferentes para "pintar" com jenipapo ou pau-de-leite, hôg, e "tingir" com urucum, kukrä. A pintura propriamente dita é o desenho preto feito com jenipapo ou pó de carvão aplicado sobre a seiva do pau-de-leite, e nos interstícios do qual se espalha o vermelho de urucum. (1978, p. 54, nota 13 )

A pintura das máscaras Kokrit-ho segue o mesmo padrão. Pintam-se os motivos com preto - uma mistura de resina de almécega (Protium $s p$.) e carvão, segundo Reis Lima (2003b) - e espalha-se ao redor o vermelho - a mesma resina misturada com urucum (Bixa orellana L.). Reis Lima (idem) sugere ainda a exploração de uma possível associação entre as pinturas corporais e a decoração das máscaras.

\section{Síntese perceptiva e seus rastros}

Reis Lima (2003b) ressalta que o comportamento dos Kokrit é constantemente perpassado ou caracterizado por "estados de liminaridade", a ponto de afirmar - e cremos que esta é uma de suas hipóteses principais - que o ritual, ao criar esses "estados", possibilita o reestabelecimento da comunicação entre os domínios do cosmo, rompida desde os tempos míticos ${ }^{23}$. Retomemos alguns elementos: 
Francisco Simôes Paes. Rastros do espírito

1. A matéria-prima das máscaras é a palha-de-buriti, elemento associado à água (pelo local onde é encontrado e seu mito de origem). Além disso, na forma de esteira - e a máscara é também uma esteira, aliás, duas - o buriti associa-se a diversos momentos da vida de um indivíduo timbira, tanto os cotidianos quanto os cerimoniais e liminares: "as esteiras fazem a ligação entre os momentos cruciais da formação do indivíduo e da construção da pessoa timbira" (Reis Lima, 2003b, p. 117).

2. O próprio nome "Kokrit-ho", outrossim, cuja etimologia relaciona água e palha, tem a conotação de "seres associados à água" ou "os companheiros da água”.

3. Nos dois rituais em que as máscaras atuam, classificados por Melatti (1978) como "rituais de iniciação", o elemento água é colocado em evidência, a despeito do fato (ou até mesmo pelo fato, por inversão) de serem realizados na época seca. O Kokrit-ho marca a passagem de um estado (a seca) para outro (a chuva). Essa alteração geoclimática não é de pouca monta para os Timbira. Não somente a organização econômica altera-se completamente, como também a organização social, refletindo-se nas relações entre as duas metades sazonais - Kamakra e Atïkmakra, no caso Ramkokamekrá, e Wakmẽye e Katamye, no caso krahó, respectivamente os pares associando-se à estação seca e à estação chuvosa -, às quais os indivíduos se associam pelo nome ${ }^{24}$. No ritual Tépyarkwa dos Krahó, por sua vez, os reclusos recebem alcunha de "espuma de água", tendo de "ficar na água" para se desenvolver.

4. No final do ritual, as "mães da máscara" lavam, com água, os (ex-) mascarados, atuando como elemento agregador ${ }^{25}$.

5. Água e palha-de-buriti são elementos mediadores (integradores e protetores) dos estados de liminaridade pelos quais passam os indivíduos ao longo de suas vidas.

6. Nos dois rituais, os Kokrit-ho caracterizam-se por "pedir comida". Esse comportamento, entretanto, não é considerado normal por um 
Krahó, que, conforme Melatti (1978), o identifica como "elemento estranho".

7. As máscaras são confeccionadas fora da aldeia e, quando o ritual termina, são simbolicamente jogadas no mato. "Isso faz com que elas venham de fora, permaneçam um certo tempo dentro da aldeia e tornem a voltar para fora, marcando as etapas de um rito de passagem inverso (...). Esse movimento geral das máscaras parece que é repetido um grande número de vezes de outra forma: os mascarados, partindo de fora da aldeia, dançam diante de cada casa, na periferia, vão até a praça e daí, um de cada vez, recolhem-se a uma casa da periferia" (Melatti, 1978, p. 271). 8. Lembremos também que um mascarado nunca se dirige a uma determinada casa pela rua circular. Nesse caso, ele vai primeiro ao pátio e dali ao caminho radial. "Os Kokrit fazem o caminho das relações que devem ser públicas, como as alianças matrimoniais, a amizade formal, a nominação. As relações com os seres sobrenaturais são do mesmo patamar, uma relação com a alteridade" (Reis Lima, 2003a, p. 78).

9. Os personagens Kokrit-ho, portanto, são seres "de fora" em reclusão dentro da aldeia.

10. Nos mitos de origem dos rituais Kokrit-ho (Ramkokamekrá e Krahó), é o isolamento, também um estado liminar, que caracteriza o contato entre os diferentes domínios cósmicos. Nesse sentido, Reis Lima (2003b) salienta que a máscara Tokaivéu é um personagem integrador do cosmo timbira, representando em seus olhos a síntese de seu universo.

Da maneira como até agora colocamos esses elementos, entretanto, eles não nos parecem suficientes para assegurar que o ritual Kokrit-ho, representado pelas fotografias de Nimuendaju, concretize seu objetivo - seja ele o estabelecimento da "condição de liminaridade", necessária para a comunicação com a alteridade, como sustenta Reis Lima (idem), ou seja simplesmente a satisfação "lúdica" do grupo que o realiza. 
Observando esses mesmos elementos, mas os dispondo de maneira diferente, temos motivos para crer que a realização do ritual é plena apenas quando seu desenvolvimento permite a saciação de todo o campo perceptivo. Esperamos, assim, conduzir estas "notas introdutórias" a uma hipótese complementar de que a mensagem do ritual, seja ela a necessidade da comunicação com os outros, seja ela a satisfação e a alegria de seus realizadores, é operada por um conjunto específico de códigos sensoriais, aqueles oferecidos pelos cinco sentidos. Acreditamos que o ritual não é dado apenas ao olhar, mas canaliza também elementos que são "para tocar", "para comer", "para cheirar" e, naturalmente, "para ouvir":

Para Ver: Ao adornar ou confeccionar as máscaras, o Timbira demonstra um rigoroso cuidado com a perfeição de sua aparência. Mais do que isso, demonstra que está disposto a participar da vida comunitária, pautada pela troca e pela comunicação com o outro. Sabemos que é principalmente nos rituais, sejam eles de nominação, de iniciação, ou realizados por quaisquer outros objetivos, que os indivíduos (principalmente crianças e adolescentes) tomam conhecimento das relações mais significativas de sua sociedade: de parentesco, de amizade formal, das propriedades-herança (prerrogativas rituais) de cada indivíduo (o seu papel na sociedade), ou seja, de aspectos da organização e reprodução social e simbólica. É principalmente nos rituais que os indivíduos entram em contato com a própria cultura de modo sistemático e coletivo, por meio dos cantos, dos mitos, da coreografia e dos ornamentos. Carneiro da Cunha, com efeito, salienta que

não cortar o cabelo e abster-se de pinturas corporais, restrições que são sempre concomitantes, significam, em todos os contextos, não participar da vida pública. Assim, foi-nos dito certa feita, os homens mais velhos não 
Revista de Antropologia, São Paulo, USP, 2004, v. 47 No 1.

pintam o corpo, apenas braços, pernas e rosto já que ficam sentados às portas das casas, de lá exortando os corredores de toras e os participantes nos rituais. Pela mesma razão, asseguram-nos então, não se pinta a criança até ela sair ao pátio, apenas se a tinge com urucum. Renunciar à ornamentação corporal implica teoricamente não correr com toras, não cantar nem dançar no pátio. (1978, p. 53-4)

Ressaltamos, novamente, que os círculos concêntricos, que caracterizam o motivo Tokaivéu, são tidos por Reis Lima (2003b) como uma síntese representativa do universo timbira.

Arriscamo-nos ainda a sugerir que toda a aldeia deve "ficar agradável" aos olhares ${ }^{26}$. Agora imaginemos um enorme pátio de terra batida no final da estação seca, as máscaras cobrindo os membros da sociedade dos Kokrit até os pés, e seus rastros pelo chão...

Para tocar: Do ato de pintar o corpo extraímos ainda um outro elemento, que é o toque proporcionado por esta atividade. Vidal (1977 e 1992) nos conta que a pintura corporal é uma atividade cotidiana entre os Kayapó-Xikrin. Desde o nascimento, a criança é introduzida nessa espécie de "modelagem do corpo". Rapidamente ela começa a apreciar o contato do pincel em seu corpo, adormecendo nos primeiros toques (a pintura de uma criança pode levar horas, sendo muito mais cuidadosa e minuciosa do que a dos adultos). A criança é o treino da mulher, e esta só passa a pintar outras mulheres, nas seçôes coletivas de pintura, quando se avalia que seu traço já está suficientemente seguro e desenvolvido.

O tato é condição sine qua non para a confecção das máscaras.

[Se] são os olhos treinados que reconhecem o broto do buriti no ponto adequado de extração da prefoliação, são as mãos habilidosas que libertam os folíolos do grelo. Nas costas do artesão, maços de folíolos brilham sob o 
Francisco Simôes Paes. Rastros do espírito

sol (...). Na aldeia os dedos flexíveis se movimentam simultaneamente entre vários pares de folíolos. A boca borrifa uniformemente a água sobre a prefoliação [para umedecer e flexibilizar a palha]. Confeccionam a esteira que será a mediadora entre os domínios da natureza, da sobrenatureza e da sociedade. (Reis Lima, 2003b, p. 117)

O buriti é ainda tateado inúmeras vezes ao longo da corrida de toras, e a dança, por sua vez, permite o êxtase corporal que, ao som da música, transpira na exposição ao sol e no contato com o solo e a coletividade. Mesmo a música não é apenas cantada ou tocada. Sua execução envolve toda uma encenação corporal que deve ser considerada. Ela não "sai" somente dos instrumentos ou da boca de quem canta, mas dos pés e das mãos que batem, das pessoas dançando, dos gritos e das onomatopéias, enfim, há um conjunto importante de elementos que precisam ser devidamente ressaltados ${ }^{27}$. Embora os pés não sejam propriamente um instrumento, eles são o principal produtor de sons percutidos, presentes na quase totalidade de músicas rituais jê, suas percutidas no chão levantando a poeira que esconde seus rastros.

O ritual encerra-se com o toque das "mães" das máscaras, quando suas mãos lavam com água os (ex-)mascarados.

Para Comer: Como foi salientado por Melatti (1978) e Reis Lima (2003b), uma das características da "condição de liminaridade" dos Kokrit é a constante solicitação que fazem por comida, chegando por isso a serem "ridicularizados pelos Me Ken (palhaços)" (idem, p. 101). Arriscamos a argumentar que "pedir comida" não é somente característica dessa "condição liminar", mas condição desta condição.

A comida, por outro lado, encerra o ritual, quando, no auge da festa, em seu momento solene, os homens realizam uma caçada coletiva e as mulheres preparam a farinha de mandioca, ingredientes para o bolo 
Revista de Antropologia, São Paulo, USP, 2004, v. 47 № 1.

de carne cozido no forno de pedras, sob a terra (Nimuendaju, 1946, p. 211$)^{28}$.

É digno de nota que a avaliação de um alimento não é dada apenas por seu gosto, mas também por seu aspecto visual, olfativo e tátil (textura, maciez etc.).

Para Cheirar: A resina utilizada para misturar e aplicar o carvão ou o urucum sobre as máscaras é identificada por Reis Lima como uma almécega (Protium sp.). Essa espécie de planta, segundo o Houaiss (2001, p. 161) pode ser também encontrada com os seguintes nomes: "breubranco", "almecegueira-cheirosa", "almecegueira-de-cheiro", "incensode-caiena", caracterizando-se por uma "resina amarela e aromática que exsuda do lentisco; almástiga, almécega-do-oriente, copal, mástica, mástiqué. Usada por suas propriedades medicinais, para mascar, como incenso e na indústria de vernizes", etimologicamente, "goma de mascar"29.

Com relação ao urucum, Nimuendaju nos informa que "os próprios índios e todas as coisas que possuem são mais ou menos vermelhas como urucum, (...) a tinta de urucum deleita a narina dos índios não menos que a cor vermelha agrada os seus olhos" (1946, p. 52).

Os monstros Kokrit, segundo Melatti (1978), estão associados à água e aos peixes, associação esta acentuada pelo fato de os Kokrit estarem presentes também no ritual Tépyarkwa, no qual atua a sociedade Tép (dos peixes). Além disso, uma outra conexão sugerida tanto pelo autor quanto pelo mito é entre os monstros Kokrit e o seu mal cheiro (cheiro de peixe potencializado?), que chega até a matar os aldeãos quando a aldeia é invadida pelos seres fedorentos que buscam resgatar a criançaKokrit seqüestrada (em reclusão dentro da aldeia). Convém lembrar ainda que no Tépyarkwa os jovens reclusos são os Koyampro ("espuma da água”) e estariam simbolicamente "na água”, entre os peixes. No rito de Kokrit-ho, seriam os Kokrit que estariam "em terra”. 
Francisco Simóes Paes. Rastros do espírito

PARA OUVIR: As homologias não param por aí. Melatti (1978) nota ainda uma interessante inversão: um dos informantes de Schultz (1950), ao falar-lhe sobre os Kokrit, substitui o "cheiro insuportável" dos monstros por uma cantiga que produziria um ruído insuportável. Esses elementos nos permitem rascunhar o seguinte quadro:

\begin{tabular}{|l|l|l|l|l|}
\hline $\begin{array}{l}\text { forma } \\
\text { kokrit }\end{array}$ & local de origem & $\begin{array}{l}\text { elemento } \\
\text { associado }\end{array}$ & cheiro & som \\
\hline $\begin{array}{l}\text { monstro } \\
\text { máscara }\end{array}$ & $\begin{array}{l}\text { água (rio) } \\
\text { terra (aldeia) }\end{array}$ & $\begin{array}{l}\text { peixe } \\
\text { buriti/ } \\
\text { almécega } \\
\text { = planta }\end{array}$ & $\begin{array}{l}\text { fedorento } \\
\text { cheiro bom }\end{array}$ & $\begin{array}{l}\text { barulhento } \\
\text { mudo }\end{array}$ \\
\hline
\end{tabular}

Estamos certos de que este quadro é bastante provisório, podendo nele ser introduzida uma série de outros elementos ${ }^{30}$.

Por outro lado, é preciso salientar que embora os Kokrit-ho sejam mudos, ou sussurrem muito baixo (ronquem surdamente), não podendo, assim, cantar, eles não são surdos e dançam ao som do cantador que trouxeram, cujo maracá foram eles que deram. Não é à toa também que, nas máscaras Tokaivéu, além de olhos, são pintados ouvidos.

Se as máscaras-esteira são mediadoras entre os domínios da natureza, da sobrenatureza e da sociedade, esta mediação só se concretiza depois que elas forem trançadas por mãos habilidosas, pintadas, cheiradas, cantadas e alimentadas.

Começamos, dessa forma, a compreender o lugar realmente essencial que cabe aos cinco sentidos na constituição do "sentido" do ritual. Como bem disse Lévi-Strauss, "a condição humana se define com todos 
Revista de Antropologia, São Paulo, USP, 2004, v. 47 № 1.

os seus atributos, inclusive aqueles que podem parecer os mais indiscutivelmente naturais" ([1964] 2004, p. 197). Em registros diferentes, portanto, o pensamento seleciona códigos diversos para "significar a significação", no caso, esse "estado de liminaridade" necessário para que o contato com a alteridade se efetue, permitindo assim que o social seja sempre (re)construído.

Assim, se inicialmente buscávamos abordar o ritual fotografado por Nimuendaju por meio de uma "ótica" antropológica (a sua e a nossa), à medida que as questóes foram sendo colocadas pudemos perceber que não se tratava efetivamente de uma "ótica" antropológica, mas de uma antropologia que, para se fazer compreensível, em relação a si e em direção ao outro (e ao ritual), precisava "digerir o mundo" por meio de todos os sentidos.

\section{Notas}

1 Carta, em alemão, datada de 25 de maio de 1939, citada em Dungs (1989, p. 194), em Grupioni (1998, p. 163) e em Hartmann (2000, p. 27). Sobre o epistolário de Nimuendaju, ver Hartmann (2000) e Grupioni (1998, principalmente o anexo III). Este escreve: "Nimuendaju era um missivista compulsivo: etnólogos, lingüistas, missionários, pesquisadores, servidores do SPI, dirigentes de museus, autoridades governamentais e índios encontravam-se entre seus correspondentes. Mantinha sua correspondência em absoluta ordem, arquivando as cartas recebidas, anotando as datas em que as respondia e fazendo cópias das que enviava. Mesmo quando estava realizando trabalho de campo, Nimuendaju mantinha os interlocutores informados de seu paradeiro e sobre os resultados, ainda que parciais, das pesquisas que estava empreendendo" (idem, p. 165). Alguns de seus interlocutores principais foram Robert Lowie, Claude Lévi-Strauss, Alfred Métraux, Heloísa Alberto Torres, Carlos Estevão e Fernando de Azevedo.

2 Para Grupioni, "seu autodidatismo, sua não-especialização aliada a amplo e profundo conhecimento dos diversos grupos indígenas estudados, as diferentes ver- 
Francisco Simôes Paes. Rastros do espírito

sões para sua morte inesperada entre os Tikuna e o fato de boa parte de sua obra não estar traduzida para o português também colaboram para sua projeção como figura lendária da disciplina” (1998, p. 167). Pelo mesmo autor, ficamos sabendo que, pouco antes de morrer, Nimuendaju entrega a Heloísa Alberto Torres, então à frente do Museu Nacional, um manuscrito: tradução - realizada, revista e completada pelo próprio Nimuendaju - de The Eastern Timbira. Junto com esse manuscrito, o arquivo do Museu Nacional abriga também, segundo Grupioni, outras tantas obras inéditas do autor, compradas de sua esposa após seu falecimento.

3 Como arqueólogo e etnólogo, Nimuendaju "reuniu conjuntos representativos de artefatos da produção material dos grupos indígenas estudados, que estão depositados em vários museus, tanto no Brasil como no exterior" (Grupioni, 1998, p. 164). Cabe notar, como o faz Reis Lima, "que os museus etnográficos brasileiros estavam constituindo seus acervos durante este período” (2003b, p. 35). Grupioni (1998) ressalta ainda que o colecionismo praticado por Nimuendaju ao longo de sua vida não era apenas ou somente uma forma de financiar suas expedições, mas constituía seu fazer etnográfico.

4 Foi certamente o etnólogo de campo que mais conheceu grupos indígenas no Brasil, quase meia centena durante os 40 anos em que explorou os rincões de um país ainda bastante desconhecido. Pesquisando em praticamente todas as regiões do Brasil, alguns dos grupos visitados por Nimuendaju foram: Aparai, Apinayé, Arara, Baenã, Baniwa, Botocudos, Canela, Curuaya, Fulniô, Guarani (vários grupos), Guajajara, Kaiguá, Kaingang, Kamakã, Kariri-Sapuyá, Kayapó, Krahó, Krikati, Maku, Matanawí, Maué, Maxakali, Munduruku, Mura, Oti, Ofaié, Palikur, Parintins, Pataxó, Pirahã, Ramkokamekrá, Sipáia, Tariana, Tembé, Terena, Tora, Tukano, Wajãpi, Wanana, Xerente, Xukuru, Yuruna.

5 É nesse contexto, portanto, que se consolida a presença das sociedades do Brasil Central no âmbito da antropologia internacional. Além de David Maybury-Lewis, que o coordenava, os principais pesquisadores associados ao Projeto Jê foram Terence Turner e Joan Banberger Turner (que realizaram suas pesquisas entre os Kayapó), Roberto DaMatta (Apinayé), Júlio Cezar Melatti (Krahó), Jean Carter Lave (Krikati) e Christopher Crocker (Bororo). Esses trabalhos, por outro lado, deram ensejo a outras pesquisas, durante as décadas de 1960, 1970 e 1980: Manuela Carneiro da Cunha, William Crocker e Maria Elisa Ladeira (os grupos Timbira), Heelas e Schwartzman (Panará), Anthony Seeger (Suyá), Lux Vidal, 
Revista de Antropologia, São Paulo, USP, 2004, v. 47 № 1.

Vanessa Lea e Gustaaf Verswijver (Kayapó), Lopes da Silva (Xavante), entre outros. Atualmente os povos Jê são divididos pela literatura especializada em três subgrupos principais, de acordo com critérios lingüísticos, geográficos e culturais: os Jê Setentrionais - que ocupam uma larga faixa entre o Nordeste brasileiro e o sudeste do Pará, dentre os quais encontramos os grupos Timbira Orientais (Ramkokamekrá-Canela, Krahó, Gaviōes e Krikati, entre outros), os Apinayé, os Kayapó, os Suyá e os Panará -; os Jê Centrais - divididos entre os Xavante (que ocupam os estados de Mato Grosso e Goiás), os Xerente (no Estado do Tocantins) e os Xakriabá (no norte de Minas Gerais) -; e os Jê Meridionais - hoje reduzidos aos povos Kaingang e Xokleng, dispersos em pequenas áreas nos estados da região sul. Para maiores detalhes, ver Grupioni (1992) e Gordon (1996).

6 Os Ramkokamekrá (ou Ramkokamekrá-Canela) habitam os cerrados próximos ao rio Tocantins, no planalto central do Brasil, no estado do Maranhão. A respeito da posição sociolingüística, ver nota anterior.

7 Todos os indivíduos masculinos de uma aldeia ramkokamekrá pertencem a uma das seis sociedades cerimoniais que, segundo Nimuendaju (1946), são: Kukén (cutia), Meken (bufōes), Khoikayu (pato), Hák (gavião), Rop (onça) e Kokrit (monstros aquáticos mascarados). O pertencimento a essas sociedades masculinas é realizado pela nominação. Algumas mulheres também estão a elas associadas. Além de pertencer a alguma dessas seis sociedades, um indivíduo (neste caso homem ou mulher) faz parte de vários outros grupos sociais: família individual, família extensa matrilinear, metades das estaçôes do ano (chuvosa ou seca), classes de idade, grupos de pátio, entre outros, sendo incorporados a eles pelo nascimento, pela idade, pelo sexo ou pelo nome.

8 Esse procedimento é o mesmo realizado quando da confecção das esteiras de palha, daí a alcunha de máscaras-esteira para esse tipo de máscara, conforme Ribeiro (1988).

9 A máscara deve esconder totalmente seu portador, de modo a "pôr em relevo os espíritos aquáticos enfatizados na matéria-prima e no ritual” (Reis Lima, 2003b, p. 24). Segundo Melatti, "é difícil identificar quem está dentro da máscara, pois a palha arrasta no chão e apaga os rastros do portador (os Krahó sabem identificar pelas pegadas cada indivíduo da aldeia em que moram)" (1978, p. 268).

10 Para uma descrição detalhada dos outros nove motivos, ver o próprio Nimuendaju (1946, p. 205) ou Reis Lima (2003, p. 63). 
Francisco Simôes Paes. Rastros do espírito

11 Reis Lima, destaca ainda a centralidade desse último personagem, escrevendo que "a reprodução de anéis concêntricos é idêntica à divisão espacial de uma aldeia timbira, cujo anel do centro é formado pelo pátio (centro da aldeia, local oficial da sociabilidade). $\mathrm{O}$ anel seguinte é formado pelas casas (local dos grupos domésticos, dos segmentos residenciais, dos quintais). O último anel é a região onde moram os bichos selvagens e os indivíduos não-timbira" (2003b, p. 114).

12 As aldeias timbira, como ocorre em vários outros grupos Jê, são circulares, as casas dispostas em um círculo recortado por caminhos radiais que levam ao pátio central. O pátio é o local ritual e político por excelência, lugar essencialmente da fabricação pública da pessoa, das danças, dos cantos e das reuniōes do conselho de anciãos. As residências são o lugar do grupo doméstico que se constitui em regime uxorilocal. Assim, o distanciamento físico das casas e o distanciamento nas relaçôes de parentesco estão diretamente associados. Ladeira (1983) salienta ainda que a maneira como as pessoas se movimentam pelos espaços da aldeia revelam o modo como elas se relacionam entre si.

13 Segundo Nimuendaju, "except for a muffled humming and a quavering in an undertone that occasionally becomes audible during their parades, the kokrit remain speechless, communication with one another and the villagers being by a patter or stamping of feet and by moving the edges of the vertical slit of the mask. The address and greet people by stamping their feet, summon them by protruding and retracting the margins of the slit" (1946, p. 210).

14 Segundo um informante Krahó de Melatti, "o Kokrit não tem vergonha de pedir; ele gosta de pedir. Quando alguém não lhe quer dar nada, ele chora; assim que essa pessoa concorda em the dar o que pede, ele pára de chorar. Ela então pede que ele dance diante da casa dela, o que o mascarado faz, recebendo em seguida o presente e indo depois para outra casa" (1978, p. 268). Os Krahó possuem o mesmo ritual que os Ramkokamekrá, com algumas diferenças, evidentemente, mas que não chegam a impedir a complementação esquemática de uma descrição por outra (para uma interpretação comparativa entre as máscaras dos dois grupos, ver Reis Lima, 2003a e 2003b).

15 Para a sequiência completa do ritual ramkokamekrá, que aqui apenas esboçamos com algumas passagens, ver Nimuendaju (1946) ou Reis Lima (2003b). Entre os Krahó, ver Melatti (1978). 
Revista de Antropologia, São Paulo, USP, 2004, v. 47 no 1.

16 Ver, por exemplo, Carneiro da Cunha (1987), DaMatta (1970 e 1973), LéviStrauss ([1964] 2004) e Viveiros de Castro (2002).

17 "Mbira" lembra também "embira", que o Novo Aurélio (Ferreira, 1999, p. 733) traz da seguinte maneira: "Do tupi. S.f. Brás. 1. Bot. Designação comum a várias espécies arbustivas da família das timeleáceas e do gênero Daphnopsis, de flores inconspícuas, e que se caracterizam por produzir boa fibra na entrecasca. Ocorrem nas matas úmidas. 2. A casca da embira-branca. 3. Qualquer casca ou cipó usado para amarrar. Var.: envira". A associação, neste caso, é intuitiva, desprovida, portanto, de comprovação.

18 Por essas e por outras razões, Castro (1994) chega a defender que esse vegetal sintetiza o sistema de metades Krahó.

19 Ver, por exemplo, Seeger $(1973 ; 1981 ; 1987)$.

20 Segundo Nimuendaju, o ritual Kokrit-ho é para os Ramkokamekrá "one of the three major festivals, one of which is chosen for performance during the years without initiations" (1946, p. 201), o que corrobora a observação de Melatti a respeito dos Krahó. Além desses e dos Ramkokamekrá, Nimuendaju (idem, p. 205-6) observou essas máscaras entre outros Timbira, como os Pukobye (gaviōes).

21 Dizem os Kayapó que todas as aves hoje existentes nasceram das penas do gavião real, quando morto pelos gêmeos gigantes (os heróis civilizadores) por ter comido viva a avó destes. Para matá-lo, entretanto, foi preciso que seu avô os colocasse num lago durante cinco ou seis semanas para crescerem. "Só então passamos a ter riquezas", dizem, referindo-se aos artefatos plumários (ver Giannini, 1991).

22 Vale lembrar também os rituais de "bater água" dos Xavante.

23 Refiro-me, com a utilização de "estados de liminaridade", às situaçóes de "passagem" em que um indivíduo, um grupo ou uma sociedade inteira pode se proporcionar de tempos em tempos mediante a realização de rituais, viagens alucinógenas, guerras etc. São estados que favorecem algum tipo de "comunicação": seja com pessoas de uma mesma sociedade, com espíritos ou com inimigos. Essas situações, poderíamos caracterizá-las pela própria tradução de Mekratamtúa Tohók, literalmente "que está vulnerável, frágil".

24 Melatti salienta que "em muitos dos ritos de que participam essas metades, um dos membros da metade Katamye produz uma série de gritos agudos e longos. Segundo um informante, trata-se do grito do gavião ir?rëkateré, que costuma gritar antes do sol sair. Segundo outro informante, trata-se do gavião h?ktikkti (tradu- 
Francisco Simôes Paes. Rastros do espírito

ção literal: 'gavião-preto'), enquanto o grito dos Wakméye seria o da rolinha tutkapregré (tradução literal: 'pombo-vermelho'). Os gritos dos Wakméye são ouvidos na estação seca, enquanto os dos Katamye, na estação chuvosa; aos gritos de cada metade, a metade contrária responde com uma espécie de recitativo" (1978, p. 82). As pinturas corporais também variam de acordo com a metade sazonal à qual pertence o indivíduo. Assegura o autor: "os membros da metade oriental [Wakméye] pintam seu corpo com traços no sentido vertical, enquanto os da ocidental [Katamye], com traços horizontais" (idem, p. 81). Na verdade, todos os elementos do cosmo krahó podem ser classificados como pertencentes a uma dessas duas metades.

25 A posição estrutural das "mães", nesse caso, é homóloga à posição de amigo formal em diversos outros rituais de tribos jê. Nos Kayapó, por exemplo, aqueles que participaram mais intensamente de um ritual, de acordo com suas prerrogativas cerimoniais, dirigem-se à casa de seus amigos formais (krobdjuo) do sexo oposto. Estes lhes passam urucum na penugem branca que trazem colada na cabeça, simbolizando a reentrada na vida cotidiana. As relaçōes entre amigos formais, nesse caso, implicam a atenuação do processo de ruptura e de reintegração. O mesmo tipo de "mediação" feita pelos krobdjuo verifica-se em diversos outros rituais e momentos de transição, como na reintegração de um jovem pai ao ngobe (conselho dos homens), quando finda seu resguardo (ver Vidal, 1977).

26 Presenciei, entre os Kayapó-Xikrin, alguns momentos de "limpeza coletiva" da aldeia (também circular, com uma casa dos homens no centro). Capinam o mato que cresce entre as casas (de preferência as mulheres) e, no pátio da aldeia, (os homens) recolhem o lixo que se acumula - cascas de frutas, fezes de cachorros etc. -, aproveitando alguma chuva que porventura caia, lavam as casas (as mulheres, as casas familiares, e os homens, a casa dos homens).

27 Ver nota 13.

28 Esse mesmo tipo de bolo é demasiadamente apreciado pelos Kayapó-Xikrin, que o chamam de kupü, e é feito geralmente em rituais, uma vez que exige um grande esforço coletivo (ver Vidal, 1977; Giannini, 1991).

29 Durante os rituais, os Kayapó-Xikrin aplicam, no alto raspado de suas cabeças, uma resina de perfume extremamente forte. Essa resina, entretanto, não é facilmente encontrada nos arredores de sua aldeia, tendo eles de subir às serras de Carajás para lá encontrarem a árvore da qual a extraem. Disseram à antropóloga 
Revista de Antropologia, São Paulo, USP, 2004, v. 47 No 1.

Clarice Cohn (informação pessoal) que, nas crianças pequenas, perfumadas com mais constância, mesmo fora de rituais, a resina serve ainda para proteger suas almas (karon) de saírem do corpo e de serem "seqüestradas" por almas que ficam peregrinando em busca de pessoas indefesas (crianças, doentes ou pessoas em estados liminares) para lhes raptar a alma.

30 Lévi-Strauss ([1964] 2004, p. 185, nota 8), citando Banner (1961), sugere a associação dos Kokrit timbira com mru kaàk, monstro aquático do universo Kayapó, em forma de cobra, "que nunca é visto, mas pode às vezes ser ouvido e farejado. Ele é responsável pelas congestōes e síncopes" - sobre mru kaàk, ver também Giannini (1991). A almécega, por sua vez, é indicada nos seguintes tratamentos: afecção dos olhos, diarréia, enteralgia, hérnia, inflamação, úlcera gangrenosa. Outras inversōes interessantes de serem exploradas referem-se aos contextos nos quais se confeccionam as esteiras propriamente ditas e as máscaras-esteira. Com relação ao lugar de confecção - dentro da aldeia, no primeiro caso, e fora da aldeia e próximo a cursos d'água, no segundo -, poderia ser dito que uma esteira trançada no seco é somente uma esteira, trançada na água é um monstro Kokrit.

\section{Bibliografia}

BALDUS, $\mathrm{H}$.

1961 "Os carimbos dos índios do Brasil", Revista do Museu Paulista, vol. 13, São Paulo.

BANNER, $\mathrm{H}$.

1961 "O índio Kayapó em seu acampamento", Boletim do Museu Paraense Emílio Goeldi, n.s., n. 13, Belém.

CARDOSO DE OLIVEIRA, R.

1988 Sobre o pensamento antropológico, Rio de Janeiro/Brasília, Tempo Brasileiro/ CNPq.

CASTRO, E.

1994 O cesto kayapó dos Krabó: uma abordagem visual, dissertação de mestrado, São Paulo, Universidade de São Paulo. 
Francisco Simōes Paes. Rastros do espírito

\section{CARNEIRO DA CUNHA, M.}

1978 Os mortos e os outros: uma análise do sistema funerário e da noção de pessoa entre os indios Krahó, São Paulo, Hucitec.

1987 "Lógica do mito e da ação: o movimento messiânico canela de 1963", in Antropologia do Brasil, São Paulo, Brasiliense.

DAMATTA, R.

1970 "Mito e Antimito entre os Timbira", in Mito e linguagem social, Rio de Janeiro, Tempo Brasileiro.

1973 "Mito e autoridade doméstica", in Ensaios de antropologia estrutural, Petrópolis, Vozes.

DUNGS, G. F.

Die Feldforschung von Curt Unckel Nimuendaju und ibre theoretisch-methodischen Grundlagen, Kön. (Publicada sob o mesmo título em Mundus Reihe Ethnologie 43, Bonn, 1991.)

FERREIRA, A. B. de H.

1999 Novo Aurélio Século XXI: o dicionário da língua portuguesa, Rio de Janeiro, Nova Fronteira.

GIANNINI, I.

1991 A ave resgatada: a impossibilidade da leveza do ser, dissertação de mestrado, São Paulo, Universidade de São Paulo.

GORDON JR., C.

1996 Aspectos da organização social jề: de Nimuendaju à década de 90, dissertação de mestrado, Rio de Janeiro, Museu Nacional.

GRUPIONI, L. D. B.

1998 Coleçōes e expediçōes vigiadas: os etnólogos no conselho de fiscalização das expediçôes artísticas e cientificas no Brasil, São Paulo, Hucitec/Anpocs.

GRUPIONI, L. D. B. (org.)

1992 Indios no Brasil, Brasília, Ministério da Educação e do Desporto. 
Revista de Antropologia, São Paulo, USP, 2004, v. 47 no 1.

HARTMANN, T.

2000 Cartas do Sertão: de Curt Nimuendaju para Carlos Estevão de Oliveira, Lisboa, Museu Nacional de Etnologia/Assírio Alvin.

HOUAISS, A. \& VILLAR, M. de S.

2001 Dicionário Houaiss da Lingua Portuguesa, Rio de Janeiro, Objetiva.

LADEIRA, M. E.

1983 "Uma aldeia timbira", in CAIUBY NOVAES, S., Habitaçôes indígenas, São Paulo, Nobel/Edusp.

LÉVI-STRAUSS, C.

[1964] 2004 O cru e o cozido (Mitológicas vol.1), São Paulo, Cosac \& Naify.

MELATTI, J. C.

1970 O sistema social krahó, tese de doutorado, São Paulo, Universidade de São Paulo.

1978 Ritos de uma tribo timbira, São Paulo, Ática.

NIMUENDAJU, C.

[1914] 1987 As lendas da criação e destruição do mundo como fundamento da religião dos Apapocúva-Guarani, São Paulo, Hucitec/Edusp.

1939 The Apinayé, Washington, Catholic University of America Press.

1942 The Serent, Los Angeles, Frederick Webb Hodge Anniversary Publication Fund.

1946 The Eastern Timbira, Berkley/Los Angeles, University of California Press. University of California Publications in American archeology and ethnology, vol. XLI, Kroeber, A. L., Gifford, E. W. \& Olson, R. L., (eds.).

REIS LIMA, M. do S.

2003a Memória trançada: um estudo das máscaras e esteiras dos Ramkokamekrá e Krahó, sob uma perspectiva etnomuseológica, São Paulo, relatório de qualificação, Universidade de São Paulo.

2003b A máscara e a esteira: a sociabilidade timbira expressa nos artefatos, dissertação de mestrado, São Paulo, Universidade de São Paulo.

RIBEIRO, B. G.

1988

Dicionário do artesanato indígena, Belo Horizonte/São Paulo, Itatiaia/Edusp. 
Francisco Simōes Paes. Rastros do espírito

SEEGER, A

1973 "O significado dos ornamentos corporais", in Os indios e nós: estudos sobre as sociedades tribais brasileiras, trad. de Carlos Byington, Rio de Janeiro, Campus, Contribuiçōes em Ciências Sociais, 6.

$1981 \quad$ Nature and Society in Central Brazil: The Suyá Indians of Mato Grosso, Cambridge/London, Harvard University Press.

1987 Why Suyá Sing: a musical anthropology of an Amazonian people, Cambridge, Cambridge University Press.

SCHULTZ, $\mathrm{H}$.

1950 "Lendas dos Índios Krahó", Revista do Museu Paulista, vol. 4: 49-152.

VIDAL, L.

1977 Morte e vida de uma sociedade indigena brasileira: os Kayapó-Xikrin do rio Cateté, São Paulo, Hucitec/Edusp.

1992 "A pintura corporal e a arte entre os Kayapó-Xikrin do Cateté", in VIDAL, L. (org.), Grafismo indigena, São Paulo, Studio Nobel/Fapesp/Edusp.

\section{VIVEIROS DE CASTRO, E.}

1987 "Nimuendaju e os Guarani", in NIMUENDAJU, C., As lendas da criação e destruição do mundo como fundamentos da religião dos Apapocúva-Guarani, São Paulo, Hucitec/Edusp.

2002

A inconstância da alma selvagem; e outros ensaios de antropologia, São Paulo, Cosac \& Naify.

ABSTRACT: From some photographs taken by Curt Nimuendaju, the article presents a bibliographical compendium about the mask rituals of the Timbira Indians of Brazil, and tries to emphasize, beyond the sight, the importance that the other four senses (touch, taste, smell and hearing) may have in the process of signification of the indian ritual.

KEY WORDS: Nimuendajú, Timbira Indians, mask ritual, five senses.

Aprovado em maio de 2004. 
Revista de Antropologia, São Paulo, USP, 2004, v. 47 no 1.

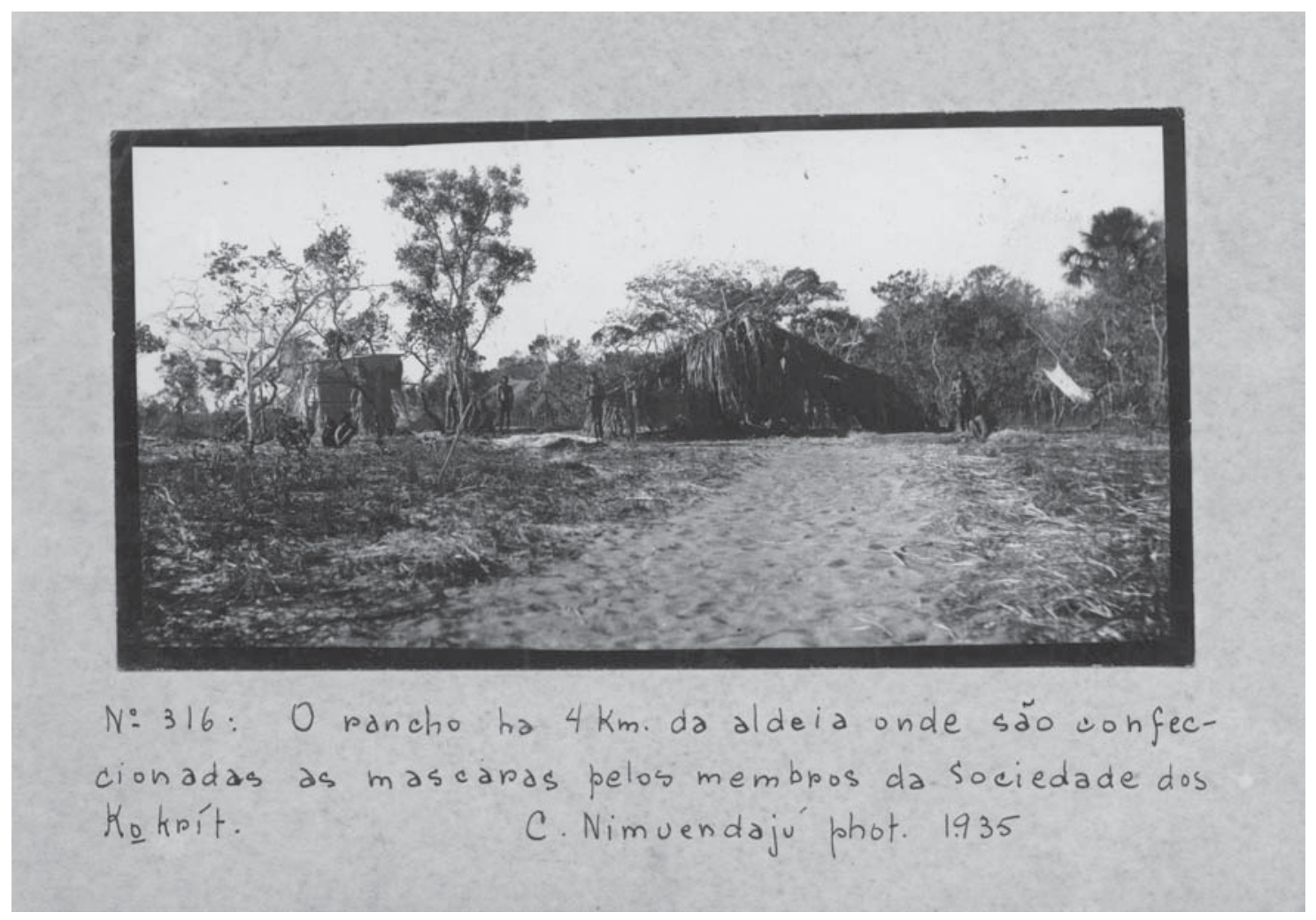

Foto 1: "O rancho a $4 \mathrm{~km}$ da aldeia onde são confeccionadas as máscaras pelos membros da Sociedade dos Kokrit”. 
Francisco Simōes Paes. Rastros do espírito

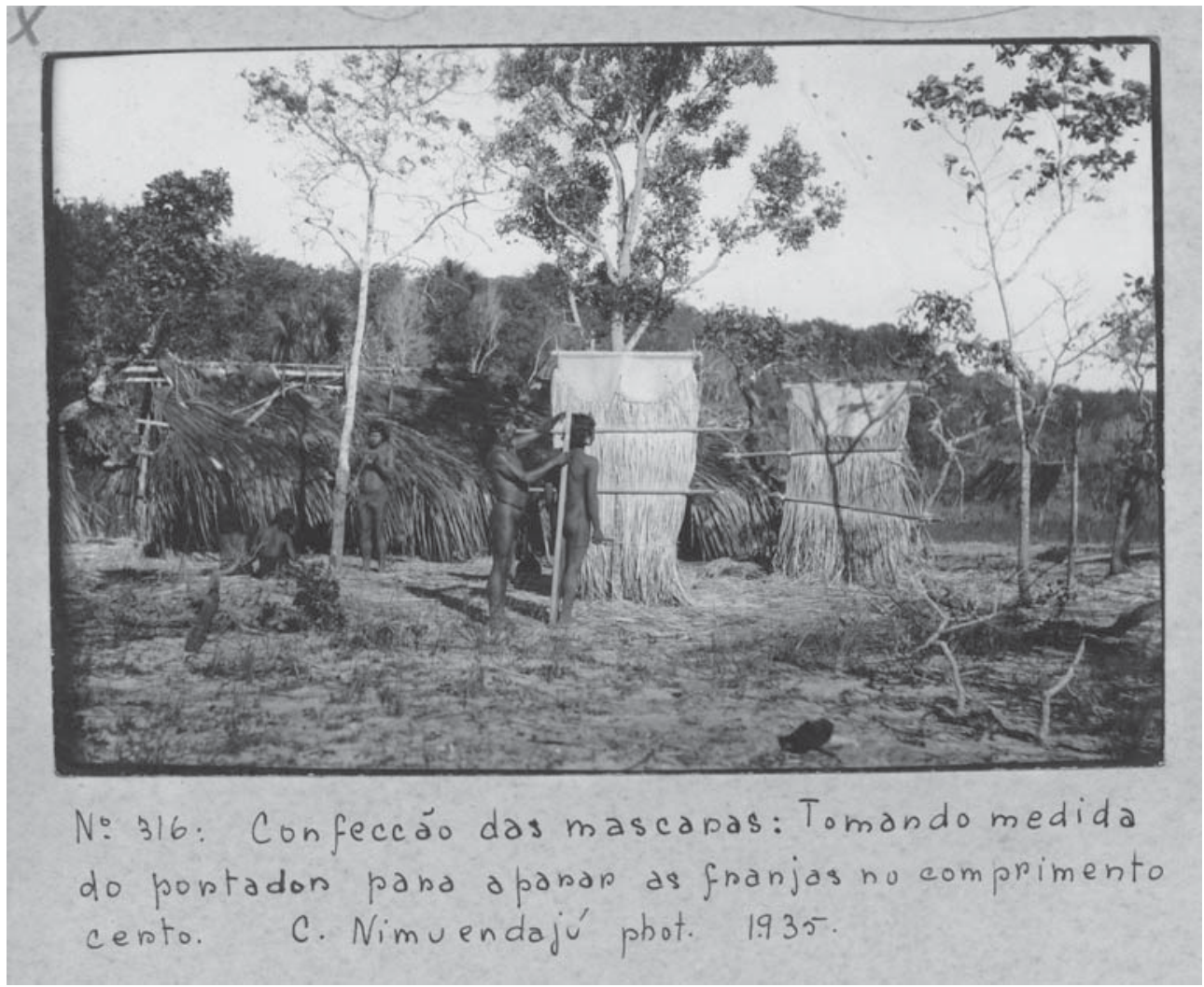

Foto 2: "Confecção das máscaras: tomando medida do portador para aparar as franjas no comprimento certo". 
Revista de Antropologia, São Paulo, USP, 2004, v. 47 no 1.

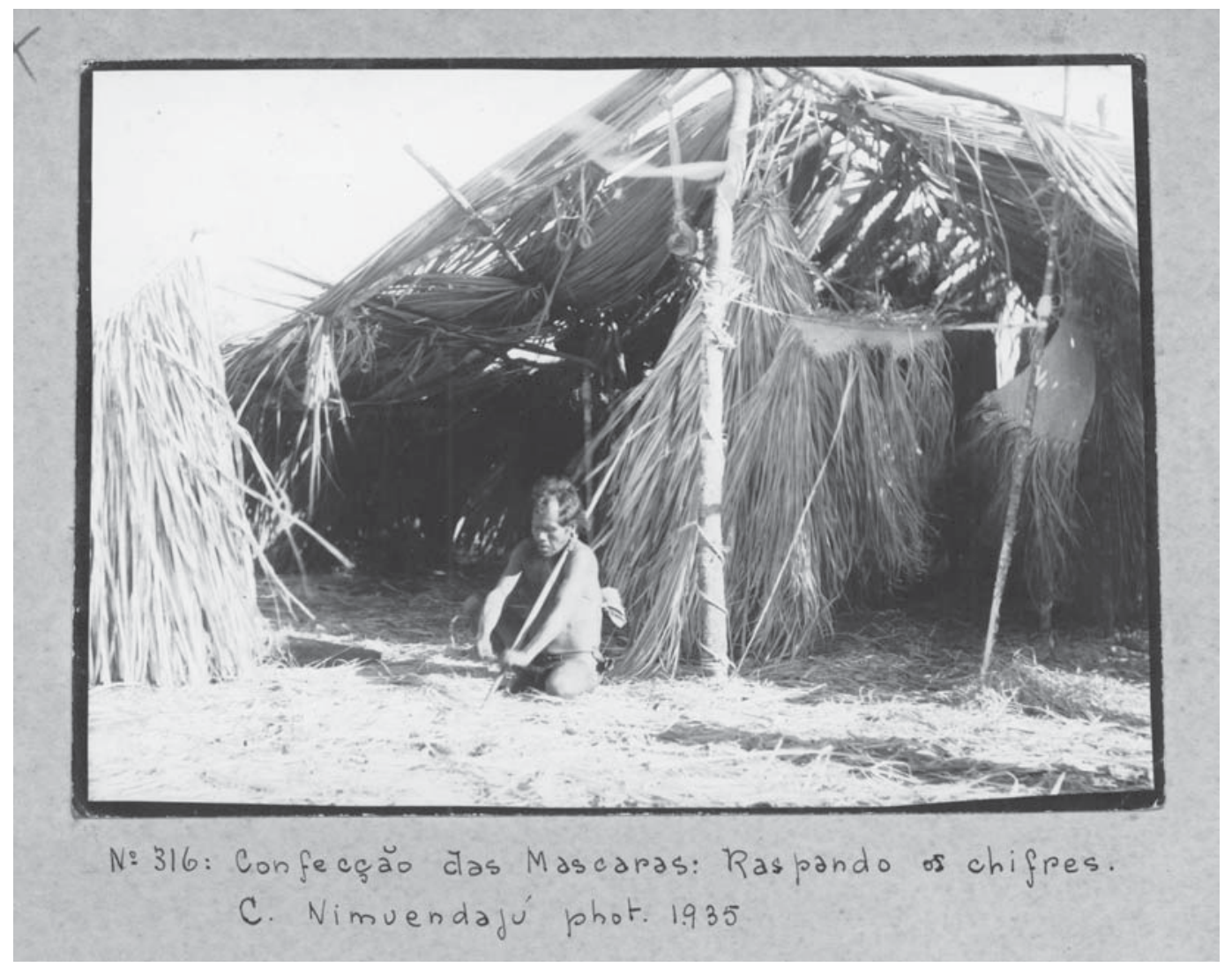

Foto 3: "Confecção das máscaras: raspando os chifres". 
Francisco Simôes Paes. Rastros do espírito

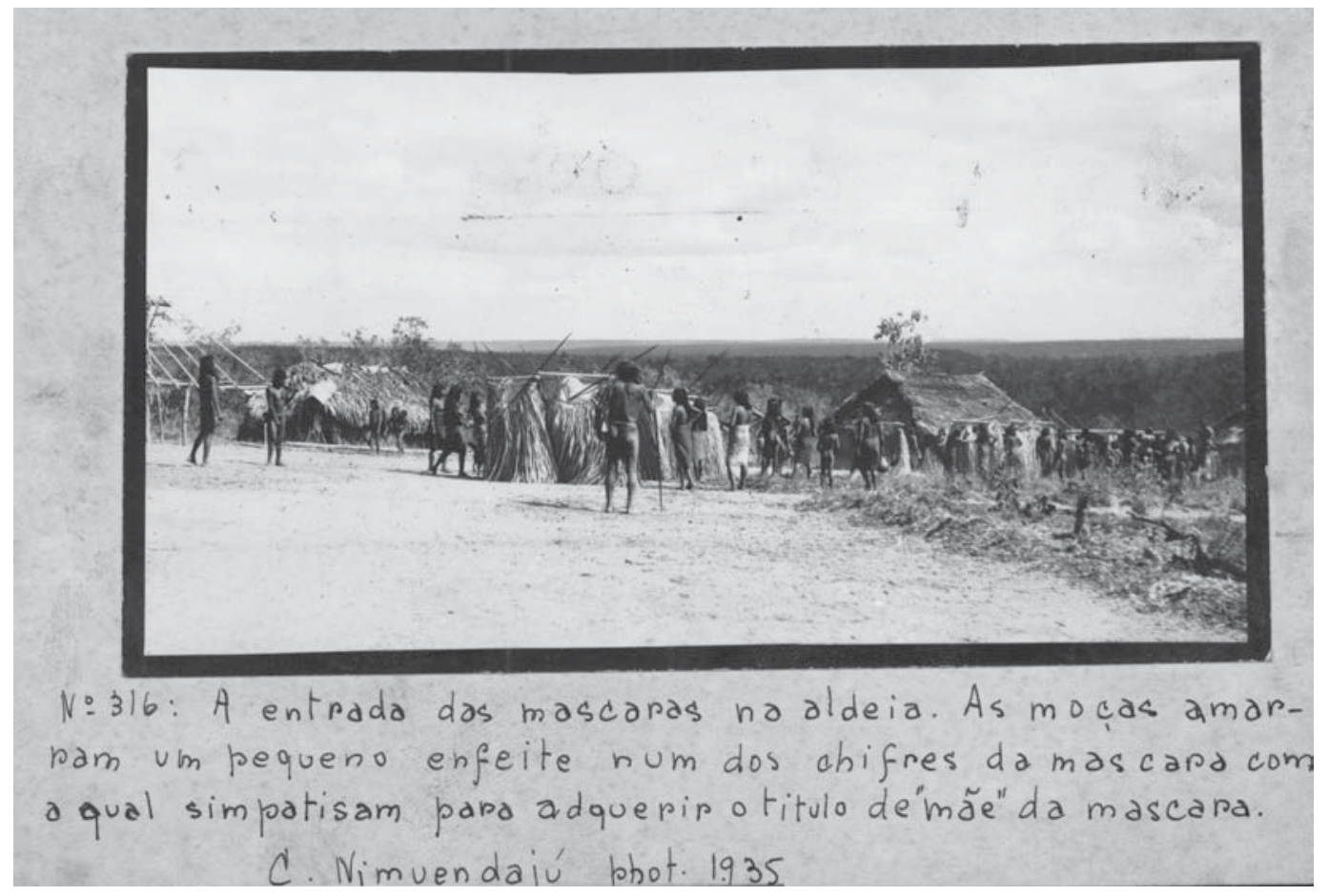

Foto 4: "A entrada das máscaras na aldeia. As moças amarram um pequeno enfeite num dos chifres da máscara com a qual simpatizam para adquirir o título de 'mãe' da máscara". 
Revista de Antropologia, São Paulo, USP, 2004, v. 47 No 1.

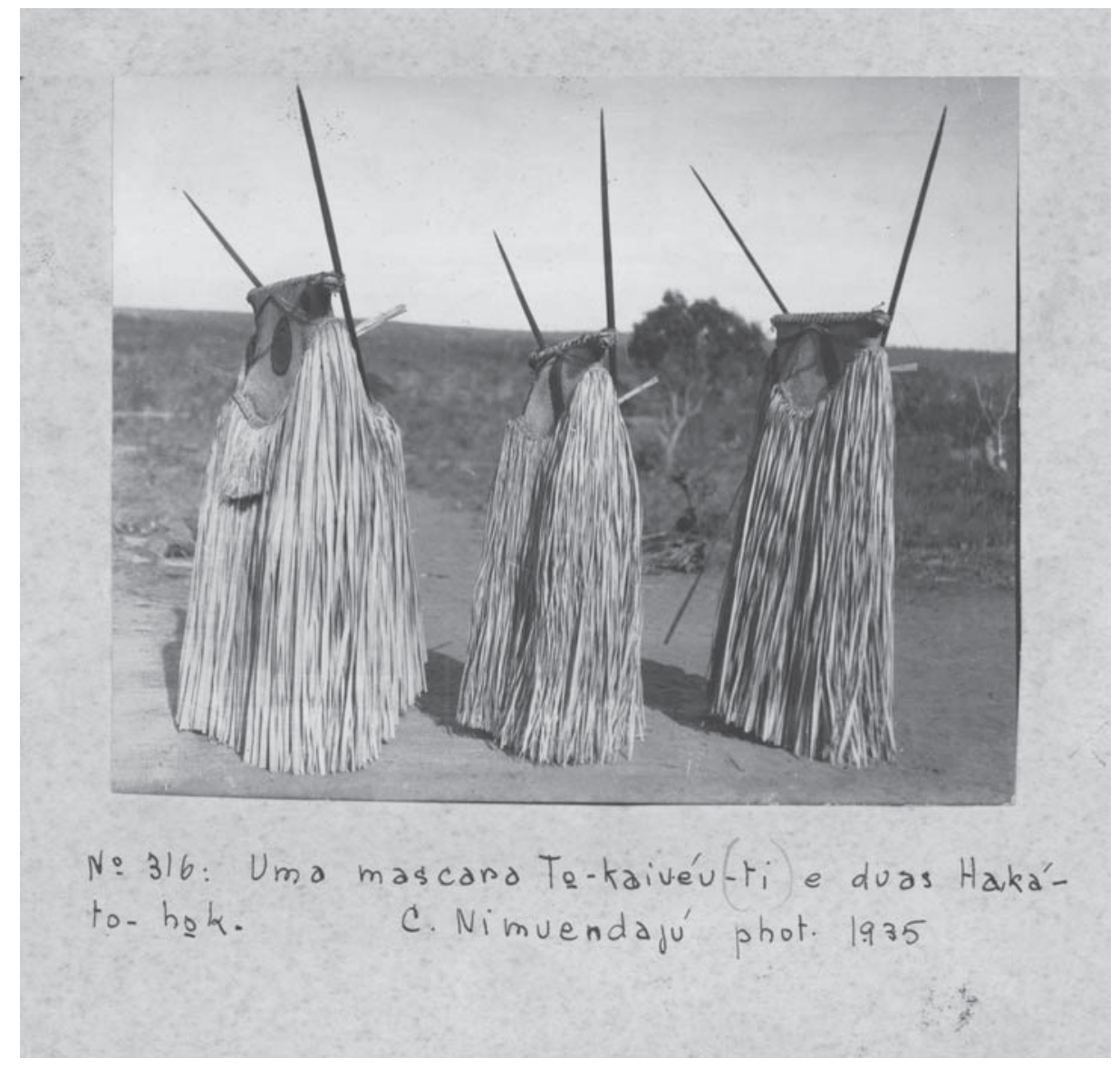

Foto 5: "Uma máscara To-kaivéu-ti e duas Haká-to-hok". 
Francisco Simôes Paes. Rastros do espírito

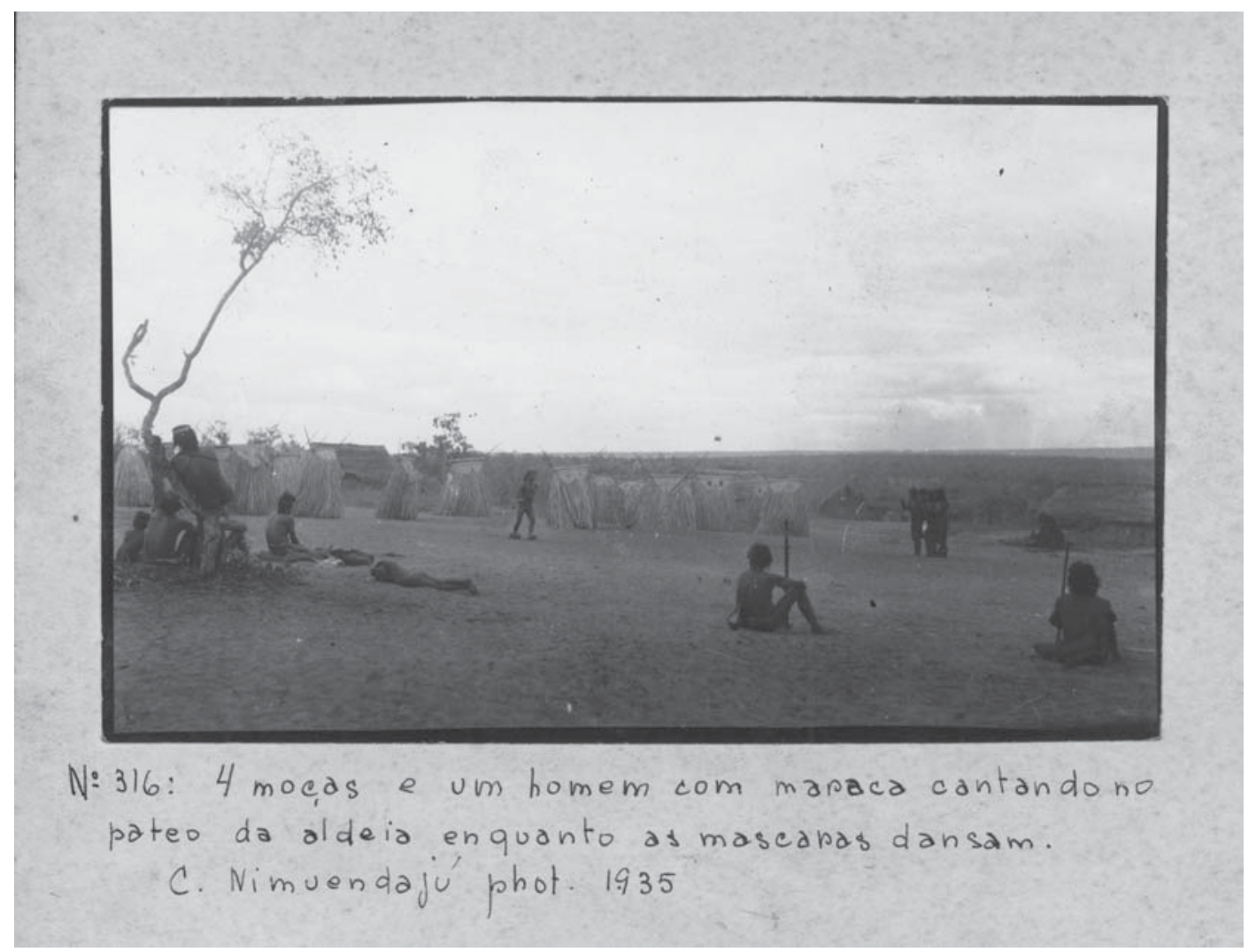

Foto 6: "Quatro moças e um homem com maracá cantando no pátio da aldeia enquanto as máscaras dançam”. 
Revista de Antropologia, São Paulo, USP, 2004, v. 47 No 1.

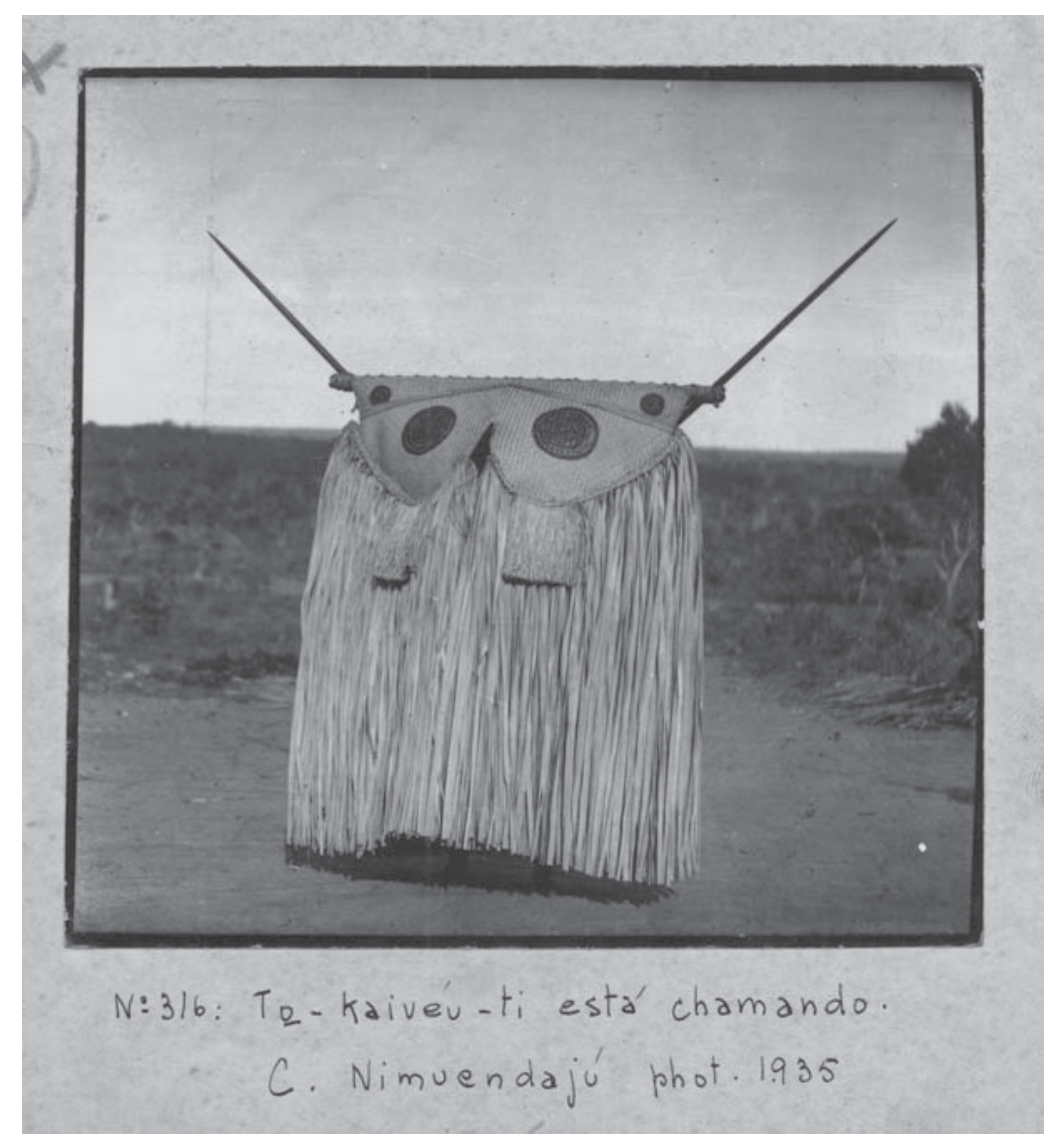

Foto 7: "To-kaivéu-ti está chamando". 
Francisco Simôes Paes. Rastros do espírito

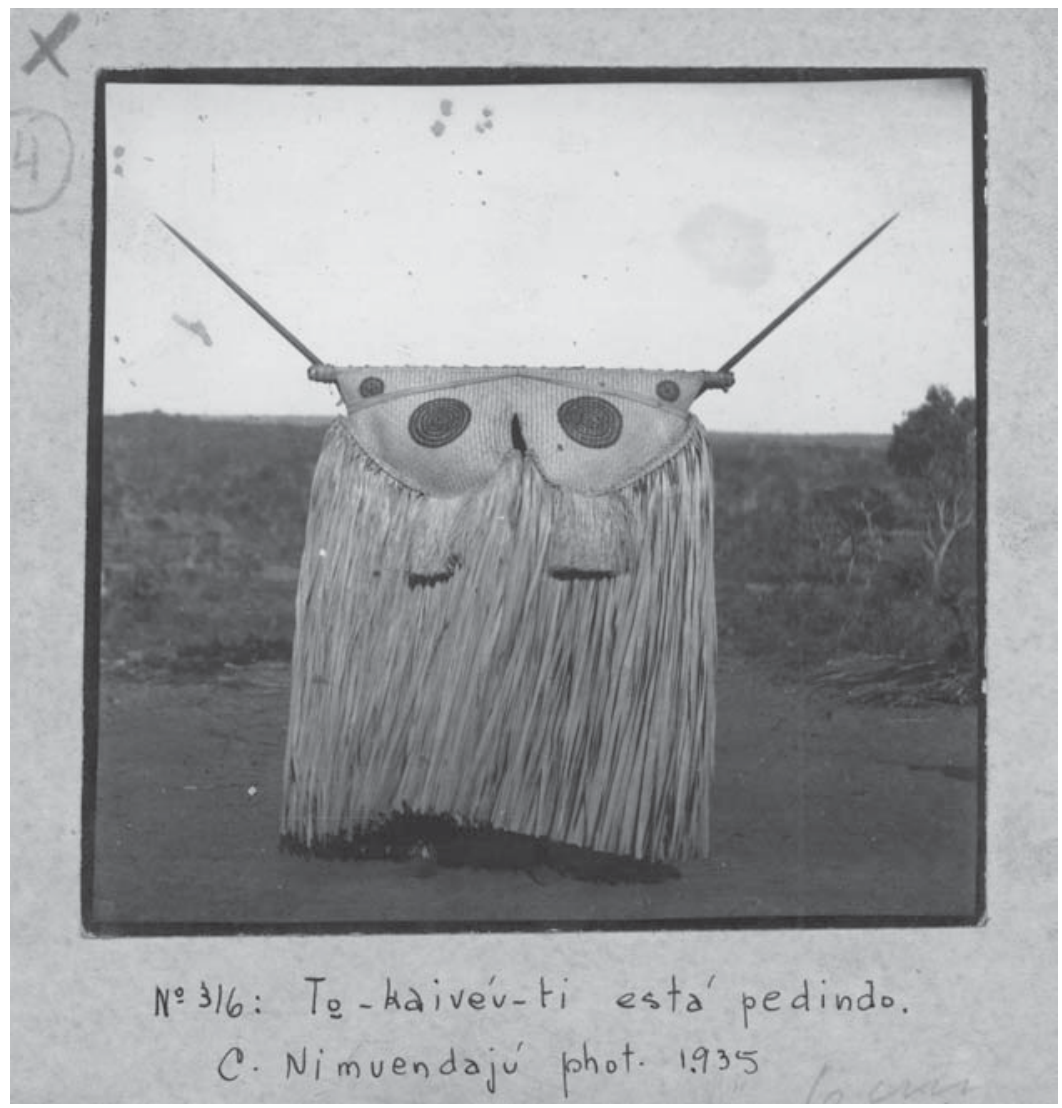

Foto 8: "To-kaivéu-ti está pedindo". 
Revista de Antropologia, São Paulo, USP, 2004, v. 47 no 1.

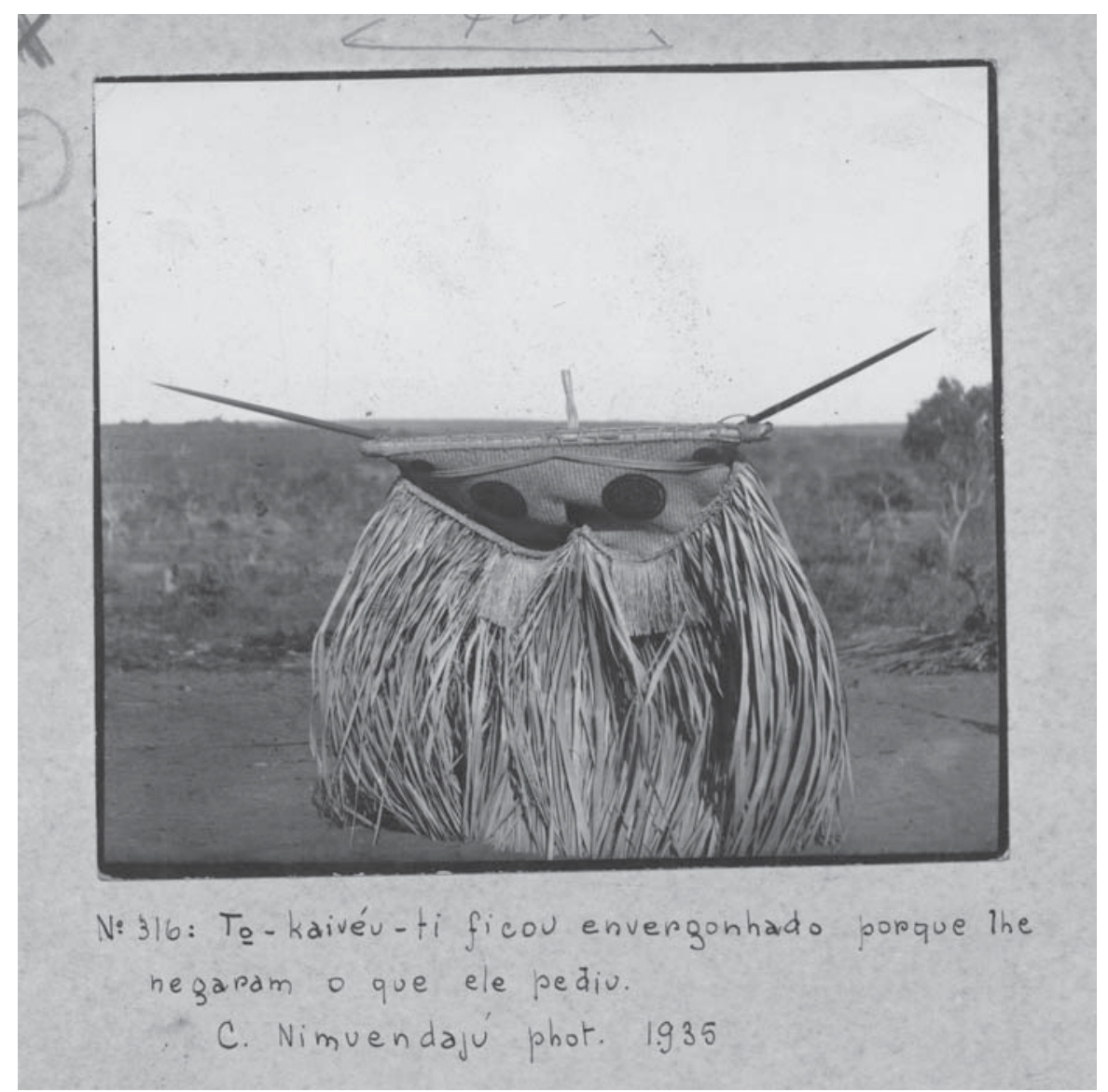

Foto 9: "To-kaivéu-ti ficou envergonhado porque lhe negaram o que ele pediu". 
Francisco Simōes Paes. Rastros do espírito

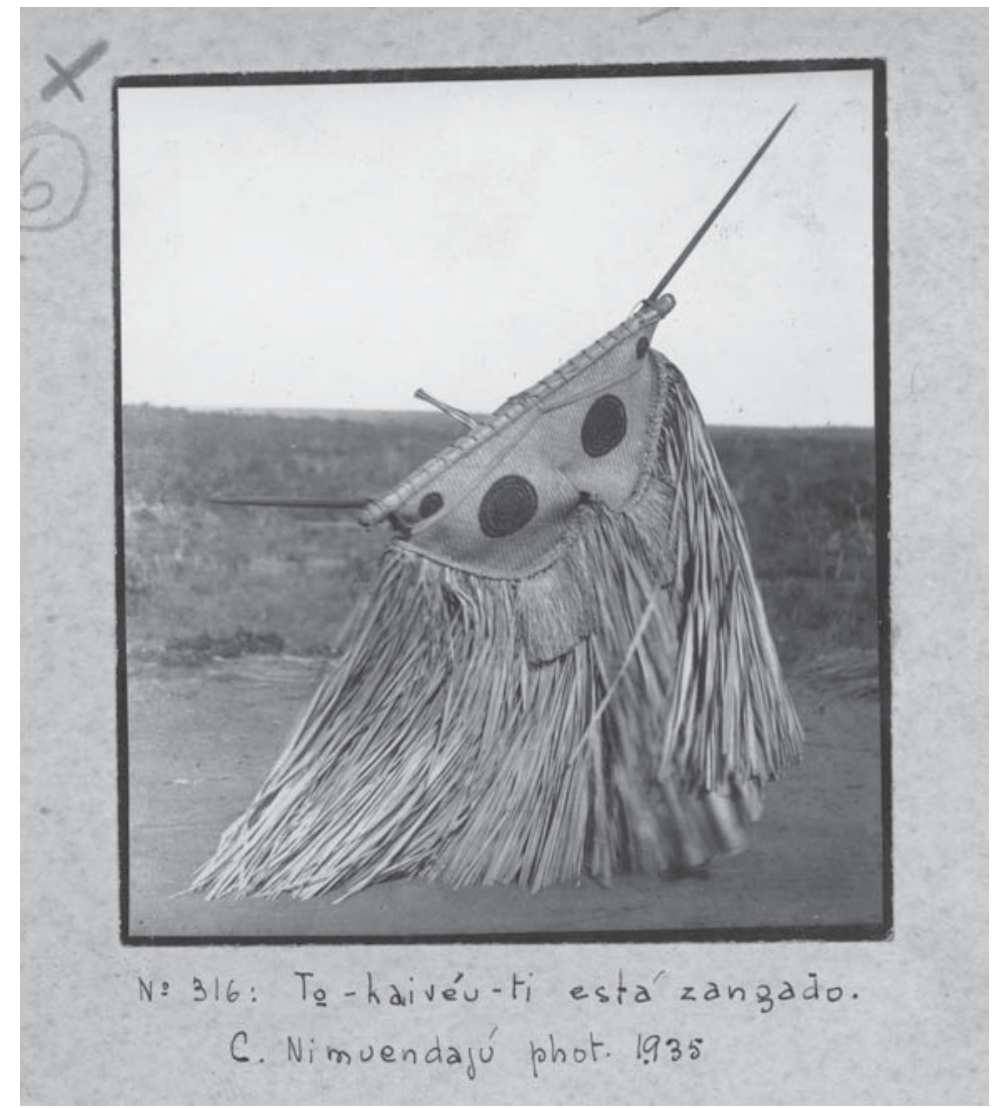

Foto 10: "To-kaivéu-ti está zangado".

$$
\text { - } 306 \text { - }
$$


Revista de Antropologia, São Paulo, USP, 2004, v. 47 No 1.

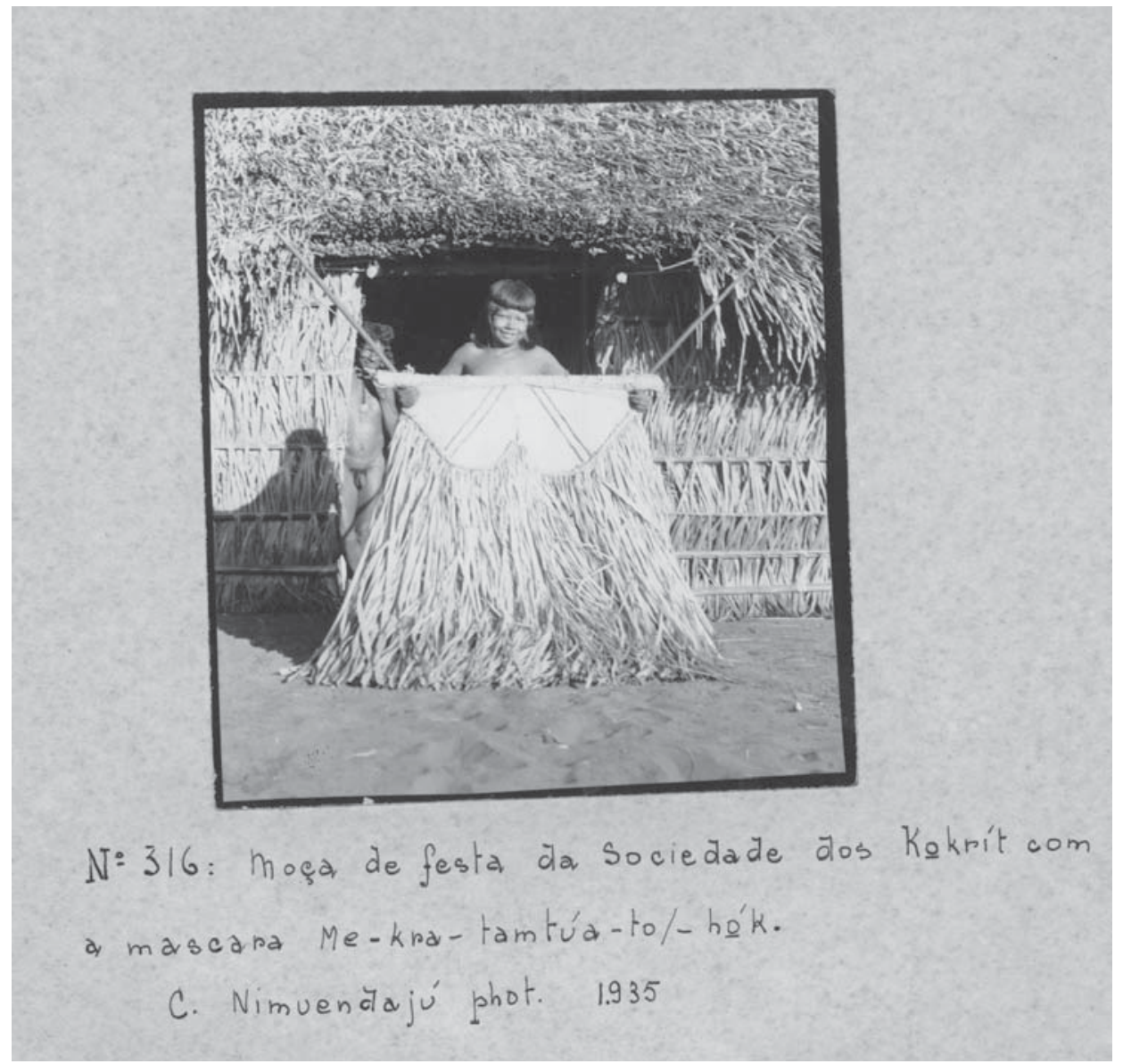

Foto 11: "Moça de festa da Sociedade dos Kokrit com a máscara Me-kra-tamtúa-to/-hók”. 